\title{
IMPLEMENTASI GAYA KEPEMIMPINAN TRANSFORMASIONAL KEPALA SEKOLAH SD IT
}

\author{
Mujibuddakwah(1) \\ SMP Muhammdiyah Kartasura Sukoharjo \\ mujibuddakwahsukses@gmail.com
}

DOI: 10.23917/varidika.v32i2.13138

\author{
Submission \\ Track: \\ Received: \\ 15 October 2020 \\ Final Revision: \\ 15 November 2020 \\ Available online: \\ 16 December 2020 \\ Corresponding Author: \\ Mujibuddakwah \\ mujibuddakwahsukses@gmail.com
}

\begin{abstract}
ABSTRAK
Tujuan penelitian ini adalah untuk mendeskripsikan implementasi gaya kepemimpinan transformasional yang ditinjau dari : 1) Perenapan dimensi idealized influence, 2) penerapan dimensi inspirational motivation, 3) penerapan dimensi intelektual stimulation, 4) penerapan dimensi individualized consideration oleh kepala sekolah dalam memimpin SDIT Muhammadiyah Al Kautsar. Penelitian ini menggunakan metode kualitatif dengan desain pendekatan fenomenologi. Hasil penelitian menunjukkan bahwa : 1) Kepala sekolah menerapkan dimensi idealized influence ditunjukkan dari integritas mengelola visi dan misi, keteladan dalam menjalankan tugas dan kemampuan dalam menyelesaikan permasalahan, 2) Kepala sekolah menerapkan dimensi inspirational motivation ditunjukkan dari kemampuan dalam menjadi insiprasi bawahan dan kemampuan memberi motivasi bawahan, 3) Kepala sekolah menerapkan dimensi intelektual stimulation ditunjukkan dari kemampuan dalam menerapkan kepemimpinan kolektif dan kemampuan dalam memberikan tindakan nyata yang memicu munculnya ide atau gagasan baru dalam menyelesaikan permasalahan melalui pemberdayaan bawahan, 4) Kepala sekolah menerapkan dimensi individualized consideration ditunjukkan dari perilaku yang bersahabat, saling adanya kepercayaan, saling menghormati dan hubungan yang sangat hangat dalam kerja sama antara pemimpin dengan anggota kelompok dan kemampuan dalam memperhatikan kebutuhan bawahan/pengikut akan pengembangan karir.
\end{abstract}

Kata kunci : kepemimpinan transformasional dan kinerja tenaga pendidik. 


\section{PENDAHULUAN}

Kinerja organisasi sangat kuat dipengaruhi oleh faktor kepemimpinan dari seorang pemimpin dalam sebuah organisasi tersebut. Jadi, sangat rasional sekali apabila keterpurukan sebuah organisasi pendidikan diakibatkan oleh kinerja kepemimpinan seorang pemimpin yang tidak bisa menyesuaikan diri dengan perubahan dan perkembangan serta tidak mampu adaptif dalam membangun strategi pendidikan sesuai dengan perubahan dan perkembangan pendidikan ataupun dengan perkembangan zaman saat ini. Seorang kepala sekolah seharusnya mampu mengelola sumber daya yang ada di sekolah secara keseluruhan dengan efektif dan efisien agar mampu mencapai tujuan pendidikan ke arah yang lebih baik. Dalam hal ini, maka diperlukan seorang kepala sekolah yang mampu mentransformasikan secara keseluruhan pengelolaan sumber daya yang terdapat di sekolah sehingga mampu menciptakan perbaikan kinerja para stakeholder sekolah agar mampu berkontribusi dalam perkembangan out put pendidikan sesuai dengan tujuan pendidikan pada era modernisasi saat ini.

Salah satu gaya kepemimpinan seorang pemimpin dalam melaksanakan tugas dan tanggungjawab kepemimpinannya adalah gaya kepemimpinan transformasional. Gaya kepemimpinan ini merupakan gaya kepemimpinan yang tepat untuk diterapkan oleh seorang pemimpin organisasi pendidikan dimana dalam hal ini adalah kepala sekolah pada era yang penuh dengan perkembangan dan tantangan seperti saat ini. Kepala sekolah yang menerapkan gaya kepemimpinan transformasional biasanya mampu mengimplementasikan suatu perubahan serta perkembangan guna memajukan sekolah. Seorang pemimpin yang mampu melakukan perubahan hanya dimiliki oleh pemimpin yang mampu mengaplikasikan gaya kepemimpinan transformasional dalam manajemen organisasi di sekolah.

SDIT Muhammadiyah Al-Kautsar Gumpang adalah sekolah yang mengalami perubahan sangat pesat. Perubahan tersebut nampak jelas setelah adanya pergantian kepemimpinan atau kepala sekolah. Kecenderungan peneliti untuk mengadakan penelitian di sekolah ini adalah cepatnya perkembangan SDIT Muhammadiyah Al-Kautsar Gumpang baik secara kualitas maupun kuantitas setelah pergantian kepala sekolah baru. Peniliti ingin mengetahui gaya kepemimpinan yang diterapkan oleh kepala sekolah SDIT Muhammadiyah Al-Kautsar dengan pendekatan gaya kepemimpinan transformasional yang meliputi empat dimensi kepemimpinan transformasional yaitu : idealized influence, inspirational motivation, intelectual stimulation dan individualized consideration.

Tujuan dari penelitian ini adalah untuk mengkaji dan mendeskripsikan : 1) Perenapan dimensi idealized influence oleh kepala sekolah dalam memimpin SDIT Muhammadiyah Al Kautsar, 2) penerapan dimensi inspirational motivation oleh kepala sekolah dalam memimpin SDIT Muhammadiyah Al Kautsar, 3) penerapan dimensi intelektual stimulation oleh kepala sekolah dalam memimpin SDIT Muhammadiyah Al Kautsar, 4) penerapan dimensi individualized consideration oleh kepala sekolah dalam memimpin SDIT Muhammadiyah Al Kautsar. 


\section{METODE PENELITIAN}

Metode penelitian ini menggunakan jenis penelitian berdasarkan pendekatannya kualitatif. Menurut Sutama (2019) penelitian kualitatif adalah penelitian yang berkaitan secara topik, observasi dan partisipan dalam wawancara tidak terstruktur, sebagian terstruktur, fokus pada kelompok-kelompok penelaahan teks kualitatif dan sebagai teknik keabsahan data seperti analisis wacana dan percakapan. Penelitian diperoleh melalui pengamatan partisipatif dalam kehidupan orang yang menjadi partisipan (Sutama, 2019).

Penelitian ini menggunakan desain penelitian etnografi. Penelitian kualitatif yang menggunakan kajian etnografi sebagai ciri khasnya dimana dalam penelititan kualitatif hal-hal subjektif (subjektivitas murni) termasuk yang diperhitungkan dalam pengumpulan dan analisis data (Sutama, 2019) Penelitian etnografi dilaksanakan di lapangan dalam waktu yang cukup lama, berbentuk observasi dan wawancara secara alamiah dengan para partisipan dalam berbagai bentuk kesempatan kegiatan serta mengumpulkan dokumen - dokumen.

\section{HASIL PENELITIAN}

\section{Metode penelitian ini menggunakan jenis penelitian berdasarkan pendekatannya}

a. Memiliki integritas dalam menjalankan tugas kepemimpinan dimana ada kesesuaian antara apa yang dikatakan dengan apa yang kerjakan.

Kepala sekolah dalam penyusunan visi, misi, tujuan dan program sekolah selalu melibatkan guru, karyawan dan stakeholder. Kepala sekolah sangat menghargai keberadaan dan fungsi dari guru, karyawan serta stakehorder. Bentuk keterlibatan dari guru, karyawan dan stakeholder sangat menentukan produk dari visi, misi, tujuan dan program sekolah. Kepala sekolah melibatkan guru dan karyawan adalah dalam rangka brainstorming terkait ide dan gagasan yang dibutuhkan untuk menjawab tantangan sekolah yang selalu berubah khususnya bagi sekolah swasta.

Kepala sekolah memberikan ruang yang sangat luas kepada bawahannya untuk dapat berkreasi merencanakan program - program unggulan bagi SDIT Muhammadiyah Al - Kautsar. Kepala sekolah juga memberikan fasilitas yang maksimal ketika kegiatan rapat kerja dilaksankan. Program - program kerja yang ada di sekolah disusun dan dikembangkan demi tercapainya tujuan sekolah. Program - program tersebut direncanakan melalui rapat kerja sebelum tahun ajaran baru dimulai. Baik program kegiatan yang sifatnya rutin ataupun non rutin. Susunan program tersebut kemudian dituangkan dalam jadwal akademik sebagai panduan kepanitian dalam melaksankan program kegiatan tersebut. Kepala sekolah memastikan berjalannya program program sekolah melalui sistem berorganisasi yang rapi. Dimulai dari perencanaan awal, kemudian kontrol program melalui memastikan proposal kegiatan telah sesuai dengan tujuan program kemudian mengevaluasi keterlaksanaannya.

b. Mampu menjadi teladan dalam bekerja menuju tercapainya target sekolah.

Strategi yang diterapkan dalam rangka mencapai visi, misi, dan program sekolah diantaranya adalah dengan berfokus pada apa yang menjadi kebutuhan dan keinginan dari masyarakat. Kepala sekolah mampu memberikan teladan dalam melaksanakan strategi pencapaian visi dan misi sekolah yaitu dengan memastikan 
semua program kegiatan yang telah diagendakan selama satu tahun telah tersusun rapi baik dari proposal maupun laporan pertanggungjawaban yang memuat evaluasi setiap kegiatan.

c. Memiliki kemampuan pemecahan masalah yang efektif

Kepala sekolah adalah problem solver utama dilingkungan sekolah, sehingga kehadirannya dalam memberikan solusi ketika terdapat masalah atau kendala dalam pengelolaan sekolah sangat dibutuhkan. Kepala menunjukkan kapasitasnya sebagai problem solver yang baik yakni dengan menempatkan masalah sesuai kewenangannya dan tidak mengambil keputusan solusi secara mandiri atau sepihak melainkan melibatkan koordinator guna mencapai solusi yang utuh.

Berdasarkan hasil temuan di atas mengenai penerapan dimensi idealized influence oleh kepala sekolah SDIT Muhammadiyah Al - Kautsar sudah sesuai dengan teori yang ada.

2. Penerapan dimensi inspirational motivation oleh kepala sekolah dalam memimpin SDIT Muhammadiyah Al Kautsar

a. Mampu menjadi inspirasi bagi bawahan untuk menjadi lebih baik

Kepala sekolah telah mengomunikasikan tujuan dan arah sekolah melalui rapat kerja, serta menginspirasi bawahan dengan tantangan untuk berubah menjadi lebih baik dalam mencapai target program dan memberikan layanan. Kepala sekolah dalam menjalankan tugas kepemimpinannya telah menciptakan program - program yang dilaksanakan dalam rangka mewujudkan visi dan tujuan sekolah serta telah mengomunikasikan kepada bawahan makna dari setiap tujuan sekolah dalam bentuk pembinaan dan pengarahan kepada guru karyawan khususnya pada saat rapat kerja rutin. Kepala sekolah mendapatkan penghormatan dari bawahan bukan sekedar karena otoritasnya yang harus dipatuhi, juga karena konsistensinya dalam perkataan dan perbuatan yang menjadikan bawahan akan mempercayai dan menghormati kepala sekolah sebagai pimpinan. Kepala sekolah sangat memperhatikan detail dari hal - hal yang bisa menguatkan kinerja guru karyawan. Keterlaksanaan kebijakan kebijakan yang beliau berikan menunjukkan adanya konsistensi apa yang beliau sampaikan atau inginkan dengan apa yang beliau kemudian kerjakan.

Kepala sekolah dalam menjalankan tugas pengelolaan sekolah selalu mempertimbangkan kondisi berdasarkan pada analisis SWAT. Khususnya adalah untuk melihat kekuatan dan kelemahan yang dimiliki baik dari unsur sumber daya manusia maupun dari sarana dan prasarana yang dimiliki sekolah maupun kekuatan dukungan dari stake holder. Kepala sekolah sangat memahami kondisi kekuatan kekuatan yang dimiliki baik oleh guru maupun yang dimiliki oleh setiap peserta didik, kemudian bapak kepala sekolah dapat memaksimalkannya melalui berbagai program untuk mewujudkan target - target yang diharapkan.

b. Memiliki kemampuan dalam memberi motivasi kepada anak buah 
Kepala Sekolah selalu meningkatkan semangat guru dan karyawan untuk selalu mengembangkan diri. Kegiatan itu dilaksanakan ketika pelaksanaan rapat kerja, breafing pagi dan rapat pembinaan Kepala sekolah senantiasa memberikan motivasi dan penghargaan kepada para guru dan karyawan untuk terus mengembangkan diri dan kompetensinya. Banyak hal yang dilakukan oleh kepala sekolah dalam mendorong semua guru dan karyawan untuk terus mengembangkan diri diantaranya dengan pemberian penghargaan bagi guru berprestasi, pemberian hadiah kepada guru yang melakukan pendampingan kepada peserta didik dalam mengikuti lomba sehingga memperoleh juara baik ditingkat kabupaten, provinsi, nasional dan internsioanal.

Kepala sekolah memberi kesempatan seluas - luas nya kepada guru dan karyawan untuk dapat tampil prestatif khususnya dalam kaitannya dengan tanggung jawabnya sebagai guru dan karyawan serta prestatif dalam kegiatan pengembangan diri baik yang dilakukan secara pribadi ataupun yang menjadi tugas khusus dari sekolah. Kepala sekolah mampu melihat kebutuhan sekolah terkait pelaksana tugas melalui pembentukan struktur organisasi sekolah. Kepala sekolah mempertimbangkan kompetensi yang dimiliki oleh setiap guru dan karyawan yang kemudian ditempatkan pada jabatan tertentu.

Kepala sekolah memberikan tugas pokok dan fungsi yang jelas kepada guru karyawan di sekolah. Sehingga dalam menjalakan tugas dan tanggungjawabnya guru karyawan telah terarah sesuai dengan tujuan sekolah. Guru karyawan yang bekerja sesuai dengan job description menjadikan iklim kerja lebih kondusif, alur kerja menjadi jelas dan terarah. Kepala sekolah juga memastikan kepada guru dan karyawan agar bekerja sesuai denga regulasi yang ada, baik regulasi dari yayasan maupun dari pemerintah, dalam hal ini dinas pendidikan kabupaten.

Kepala sekolah sangat memperhatikan keberhasilan program dengan memberikan fasilatas penunjang kesuksesan program. Kepala sekolah memastikan apa yang menjadi kebutuhan guru dan karyawan di sekolah untuk dapat berkerja dan berkarya dengan maksimal harus terpenuhi dengan baik. Fasiltis yang diberikan kepada guru dan karyawan bisa dalam bentuk pembiayaan dan atau penyediaan sarana dan prasarana kerja.

Berdasarkan hasil temuan di atas mengenai penerapan dimensi inspirational motivation oleh kepala sekolah SDIT Muhammadiyah Al - Kautsar sudah sesuai dengan teori yang ada.

\section{Penerapan dimensi intelektual stimulation oleh kepala sekolah dalam memimpin SDIT Muhammadiyah Al Kautsar.}

\section{a. Mampu menerapkan kepemimpinan kolektif.}

Kepala sekolah melaksanakan pembentukan struktur organisasi sekolah dimana guru dan karyawan yang mendapatkan tanggungjawab dan tugas diberikan keleluasaan dan kewenangan oleh kepala sekolah dalam menjalankan apa yang menjadi tugas guru dan karyawan tersebut. Struktur orgnisasi disusun dan ditetapkan oleh kepala sekolah di awal tahun ajaran baru. Pemilihan guru dan karyawan yang menjabat dalam struktur 
organisasi menjadi kewenangan kepala sekolah untuk mempertimbangkannya dari segi kompetensi guru dan karyawan yang ditunjuk. Guru dan karyawan yang ditunjuk unutk menduduki jabatan struktural tertentu mendapatkan garis - garis kerja berupa tugas pokok dan fungsi jabatan.

Kepala sekolah mampu memberikan kewenangan dan keleluasaan kepada guru dan karyawan sekolah untuk merencanakan program disetiap awal tahun ajaran dan mengembangkan program - program yang ada menjadi lebih baik. Kepala sekolah sangat terbuka dengan ide dan gagasan yang lahir dari guru dan karyawan, terlebih ide dan gagasan tersebut adalah untuk percepatan terwujudnya tujuan sekolah.

Kepala sekolah senantiasa memantau berjalannya program yang ada di sekolah, khususnya program - program yang memberdayakan peserta didik untuk dapat tampil atau mengikuti ajang kompetisi berdasarkan minat, bakat dan kemampuan peserta didik. The school of champion adalah slogan yang dimasifkan oleh sekolah di masyarakat dengan maksud agar terbangun brand sekolah yang prestatif. Kepala sekolah memastikan pemetaan peserta didik yang memiliki minat dan bakat dilaksanakan dengan baik. Kepala sekolah mendorong kepada guru unutk tampil prestatif dengan memberikan pendampingan dan bimbingan yang maksimal kepada peserta didik yang diproyeksikan untuk mengikuti kompetisi

b. Mampu memberikan tindakan nyata yang memicu munculnya ide atau gagasan baru dalam menyelesaikan permasalahan melalui pemberdayaan bawahan.

Kepala sekolah dalam melaksanakan tugasnya sebagai pemimpin sekolah telah memperhatikan kebutuhan guru dan karyawan dalam hal peningkatan kompetensi mereka sebagai pendidik dan tenaga kependidikan. kepala sekolah sangat memperhatikan apa yang menjadi kebutuhan dari guru dan karyawan untuk dapat bekerja dengan rasa nyaman sehingga mampu memenuhi profesionalisme dalam bekerja di sekolah. Kepala sekolah telah mampu memberikan fasilitas kesejahteraan dan melengkapi sarana serta prasana penunjang guru dan karyawan dalam bekerja memberikan layanan pendidikan.

Kepala sekolah mampu menunjukkan diri sebagai pribadi yang ramah kepada siapa saja. Hal ini menghadirkan kesan bersahabat pada diri beliau sehingga orang yang bersinggungan dengan beliau akan mudah untuk merasa nyaman. Pola komunikasi yang diterapkan oleh kepala sekolah sama sekali tidak membedakan herarki struktur organisasi sekolah. Kepala sekolah merancang kegiatan - kegiatan penguatan untuk membangun hubungan kerja yang dinamis diantara guru dan karyawan. Kepala sekolah juga telah memberikan tugas - tugas menantang kepada guru dan karyawan untuk mampu menunjukkan prestasi diri.

Berdasarkan hasil temuan di atas mengenai penerapan dimensi intelektual stimulation oleh kepala sekolah SDIT Muhammadiyah Al - Kautsar sudah sesuai dengan teori yang ada.

\section{Penerapan dimensi individualized consideration oleh kepala sekolah dalam memimpin SDIT Muhammadiyah Al Kautsar}


a. Menunjukkan perilaku yang bersahabat, saling adanya kepercayaan, saling menghormati dan hubungan yang sangat hangat dalam kerja sama antara pemimpin dengan anggota kelompok.

Kepala sekolah dalam menjalankan kepemimpinannya telah menciptakan suasana iklim kerja yang nyaman melalui karakter keterbukaannya ketika berinteraksi dengan guru dan karyawan bai pada forum resmi maupun tidak resmi. Kepala sekolah sangat memperhatikan bawahan. Perhatian tersebut sering disampaikan dalam wujud apresiasi atau penghargaan. Salah satunya adalah adanya kebijakan penghargaan penambahan masa kerja bagi guru atau karyawan yang telah menyelesaikan studi lanjut. Selain itu beliau juga sangat menghargai kreatifitas bagi guru atau karyawan yang aktif dalam kepenulisan. Hal ini dapat dilihat dari kebijakan beliau yang memberikan insentif tambahan bagi guru karyawan yang kreatif dalam menulis.

b. Mampu memperhatikan kebutuhan bawahan/pengikut akan pengembangan karir.

Kepala sekolah sangat memperhatikan perkembangan kompetensi guru dan karyawan. Perhatian tersebut diwujudkan dalam bentuk kegiatan pelatihan. Kegiatan pelatihan guru dan karyawan diberikan sesuai dengan kebutuhan peningkatan kompetensi. Kegitan pelatihan guru dan karyawan diantaranya dalam bentuk seminar, in house training, workshop, dan lain - lain. Peningkatan kompetensi guru menjadi keharusan bagi sekolah swasta yang dituntut untuk selalu berbenah dan berupaya mengikuti perkembangan pendidikan di Indonesia. kepala sekolah memberikan kesempatan kepada guru dan karyawan untuk mengikuti pendidikan lanjut. Kepala sekolah memberi kelonggaran bagi guru dan karyawan yang sedang menempuh pendidikan lanjut, yakni dengan pengurangan beban tugas dan kelonggaran waktu. Kepala sekolah memiliki progam peningkatakan kompetensi guru karyawan melalui pemberian fasilitas pembiayaan pendidikan kepada guru dan karyawan yang melanjutkan pendidikan ke jenjang lebih tinggi.

Berdasarkan hasil temuan di atas mengenai penerapan dimensi individualized consideration oleh kepala sekolah SDIT Muhammadiyah Al Kautsar sudah sesuai dengan teori yang ada.

\section{PEMBAHASAN}

1. Perenapan dimensi idealized influence oleh kepala sekolah dalam memimpin SDIT Muhammadiyah Al - Kautsar

a. Memiliki integritas dalam menjalankan tugas kepemimpinan dimana ada kesesuaian antara apa yang dikatakan dengan apa yang kerjakan.

Kepala sekolah dalam penyusunan visi, misi, tujuan dan program sekolah selalu melibatkan guru, karyawan dan stakeholder. Kepala sekolah sangat menghargai keberadaan dan fungsi dari guru, karyawan serta stakehorder. Bentuk keterlibatan dari guru, karyawan dan stakeholder sangat menentukan produk dari visi, misi, tujuan dan program sekolah. Kepala sekolah melibatkan guru dan 
karyawan adalah dalam rangka brainstorming terkait ide dan gagasan yang dibutuhkan untuk menjawab tantangan sekolah yang selalu berubah khususnya bagi sekolah swasta.

Kepala sekolah memberikan ruang yang sangat luas kepada bawahannya untuk dapat berkreasi merencanakan program - program unggulan bagi SDIT Muhammadiyah Al - Kautsar. Kepala sekolah juga memberikan fasilitas yang maksimal ketika kegiatan rapat kerja dilaksankan. Program - program kerja yang ada di sekolah disusun dan dikembangkan demi tercapainya tujuan sekolah. Program - program tersebut direncanakan melalui rapat kerja sebelum tahun ajaran baru dimulai. Baik program kegiatan yang sifatnya rutin ataupun non rutin. Susunan program tersebut kemudian dituangkan dalam jadwal akademik sebagai panduan kepanitian dalam melaksankan program kegiatan tersebut. Kepala sekolah memastikan berjalannya program - program sekolah melalui sistem berorganisasi yang rapi. Dimulai dari perencanaan awal, kemudian kontrol program melalui memastikan proposal kegiatan telah sesuai dengan tujuan program kemudian mengevaluasi keterlaksanaannya.

Temuan di atas sesuai dengan apa yang disampaikan Imam Machali (2016: 99) bahwa Kepemimpinan transformatif dapat didefinisikan sebagai kemampuan seorang pemimpin dalam bekerja dengan dan/atau melalui orang lain untuk menstransformasikan secara optimal sumber daya organisasi dalam rangka mencapai tujuan sesuai dengan target tercapainya yang telah ditetapkan

b. Mampu menjadi teladan dalam bekerja menuju tercapainya target sekolah.

Strategi yang diterapkan dalam rangka mencapai visi, misi, dan program sekolah diantaranya adalah dengan berfokus pada apa yang menjadi kebutuhan dan keinginan dari masyarakat. Kepala sekolah mampu memberikan teladan dalam melaksanakan strategi pencapaian visi dan misi sekolah yaitu dengan memastikan semua program kegiatan yang telah diagendakan selama satu tahun telah tersusun rapi baik dari proposal maupun laporan pertanggungjawaban yang memuat evaluasi setiap kegiatan.

Temuan di atas sesuai dengan apa dinyatakan (Lee, 2006) dimana kata integrity berasal dari akar kata "integrated", yang berarti berbagai bagian dari karakter dan keterampilan berperan aktif dalam diri kita, yang tampak dari keputusan-keputusan tindakan-tindakan kita. Untuk dapat menghasilkan kinerja baik di tempat kerja, seseorang harus memiliki dalam dirinya kemampuankemapuan seperti, jujur, berani, berdaya juang, membangun hubungan baik, pandai mengorganisasikan diri sendiri, teratur, dan terencana dengan baik

c. Memiliki kemampuan pemecahan masalah yang efektif

Kepala sekolah adalah problem solver utama dilingkungan sekolah, sehingga kehadirannya dalam memberikan solusi ketika terdapat masalah atau kendala dalam pengelolaan sekolah sangat dibutuhkan. Kepala menunjukkan kapasitasnya sebagai problem solver yang baik yakni dengan menempatkan masalah 
sesuai kewenangannya dan tidak mengambil keputusan solusi secara mandiri atau sepihak melainkan melibatkan koordinator guna mencapai solusi yang utuh.

Temuan di atas sesuai dengan apa yang disampaikan Kenneth Leithwood dan Doris Jantzi dalam penelitiannya yang berjudul The Effects Of Transformational Leadership On Organizational Conditions And Student Engagement With School menjelaskan bahwa kepemimpinan transformasional yang didukung tingkat motivasi dan komitmen yang tinggi berpengaruh dalam menyelesaikan masalah substansial pada organisasi

\section{Penerapan dimensi inspirational motivation oleh kepala sekolah dalam memimpin SDIT Muhammadiyah Al Kautsar}

a. Mampu menjadi inspirasi bagi bawahan untuk menjadi lebih baik

Kepala sekolah telah mengomunikasikan tujuan dan arah sekolah melalui rapat kerja, serta menginspirasi bawahan dengan tantangan untuk berubah menjadi lebih baik dalam mencapai target program dan memberikan layanan. Kepala sekolah dalam menjalankan tugas kepemimpinannya telah menciptakan program - program yang dilaksanakan dalam rangka mewujudkan visi dan tujuan sekolah serta telah mengomunikasikan kepada bawahan makna dari setiap tujuan sekolah dalam bentuk pembinaan dan pengarahan kepada guru karyawan khususnya pada saat rapat kerja rutin. Kepala sekolah mendapatkan penghormatan dari bawahan bukan sekedar karena otoritasnya yang harus dipatuhi, juga karena konsistensinya dalam perkataan dan perbuatan yang menjadikan bawahan akan mempercayai dan menghormati kepala sekolah sebagai pimpinan. Kepala sekolah sangat memperhatikan detail dari hal - hal yang bisa menguatkan kinerja guru karyawan. Keterlaksanaan kebijakan kebijakan yang beliau berikan menunjukkan adanya konsistensi apa yang beliau sampaikan atau inginkan dengan apa yang beliau kemudian kerjakan.

Kepala sekolah dalam menjalankan tugas pengelolaan sekolah selalu mempertimbangkan kondisi berdasarkan pada analisis SWAT. Khususnya adalah untuk melihat kekuatan dan kelemahan yang dimiliki baik dari unsur sumber daya manusia maupun dari sarana dan prasarana yang dimiliki sekolah maupun kekuatan dukungan dari stake holder. Kepala sekolah sangat memahami kondisi kekuatan kekuatan yang dimiliki baik oleh guru maupun yang dimiliki oleh setiap peserta didik, kemudian bapak kepala sekolah dapat memaksimalkannya melalui berbagai program untuk mewujudkan target - target yang diharapkan.

Temuan di atas sesuai dengan apa yang disampaikan Eliophotou (2016) yang menunjukkan pentingnya mengadopsi perilaku kepemimpinan transformasional dalam praktik di unit sekolah. Pemimpin dengan gaya transformasional dapat menginspirasi guru untuk mencapai hasil yang lebih banyak dan menjadi lebih berkomitmen terhadap pekerjaan mereka dan terhadap misi organisasi

b. Memiliki kemampuan dalam memberi motivasi kepada anak buah

Kepala Sekolah selalu meningkatkan semangat guru dan karyawan untuk selalu mengembangkan diri. Kegiatan itu dilaksanakan ketika pelaksanaan rapat kerja, breafing pagi dan rapat pembinaan Kepala sekolah senantiasa memberikan 
motivasi dan penghargaan kepada para guru dan karyawan untuk terus mengembangkan diri dan kompetensinya. Banyak hal yang dilakukan oleh kepala sekolah dalam mendorong semua guru dan karyawan untuk terus mengembangkan diri diantaranya dengan pemberian penghargaan bagi guru berprestasi, pemberian hadiah kepada guru yang melakukan pendampingan kepada peserta didik dalam mengikuti lomba sehingga memperoleh juara baik ditingkat kabupaten, provinsi, nasional dan internsioanal.

Temuan di atas sesuai dengan hasil penelitian Roesminingsih (2014) yang menunjukkan manajemen Mutmainnah merupakan implementasi kepemimpinan transformasional yang dapat merubah mindset bawahan dari pola lama menjadi pola baru, melalui motivasi personal kepala sekolah. Kepala sekolah berhasil membawa guru dan karyawan berpikiran maju dalam pengelolaan sekolah melalui motivasi berkemajuan yang selalu diberikan.

Kepala sekolah memberi kesempatan seluas - luas nya kepada guru dan karyawan untuk dapat tampil prestatif khususnya dalam kaitannya dengan tanggung jawabnya sebagai guru dan karyawan serta prestatif dalam kegiatan pengembangan diri baik yang dilakukan secara pribadi ataupun yang menjadi tugas khusus dari sekolah. Kepala sekolah mampu melihat kebutuhan sekolah terkait pelaksana tugas melalui pembentukan struktur organisasi sekolah. Kepala sekolah mempertimbangkan kompetensi yang dimiliki oleh setiap guru dan karyawan yang kemudian ditempatkan pada jabatan tertentu.

Kepala sekolah memberikan tugas pokok dan fungsi yang jelas kepada guru karyawan di sekolah. Sehingga dalam menjalakan tugas dan tanggungjawabnya guru karyawan telah terarah sesuai dengan tujuan sekolah. Guru karyawan yang bekerja sesuai dengan job description menjadikan iklim kerja lebih kondusif, alur kerja menjadi jelas dan terarah. Kepala sekolah juga memastikan kepada guru dan karyawan agar bekerja sesuai denga regulasi yang ada, baik regulasi dari yayasan maupun dari pemerintah, dalam hal ini dinas pendidikan kabupaten.

Kepala sekolah sangat memperhatikan keberhasilan program dengan memberikan fasilatas penunjang kesuksesan program. Kepala sekolah memastikan apa yang menjadi kebutuhan guru dan karyawan di sekolah untuk dapat berkerja dan berkarya dengan maksimal harus terpenuhi dengan baik. Fasiltis yang diberikan kepada guru dan karyawan bisa dalam bentuk pembiayaan dan atau penyediaan sarana dan prasarana kerja.

Temuan - temuan di atas sesuai dengan apa yang disampaikan Mulyasa (2017: 17) kepemimpinan pendidikan berkaitan dengan masalah kepala sekolah dalam meningkatkan kesempatan untuk mengadakan pertemuan secara efektif dengan para guru dalam situasi yang kondusif. Perilaku kepala sekolah harus dapat mendorong kinerja para guru dengan menunjukkan rasa bersahabat, dekat, dan penuh pertimbangan terhadap para guru, baik sebagai individu maupun sebagai kelompok. 


\section{Penerapan dimensi intelektual stimulation oleh kepala sekolah dalam memimpin SDIT Muhammadiyah Al Kautsar.}

a. Mampu menerapkan kepemimpinan kolektif.

Kepala sekolah melaksanakan pembentukan struktur organisasi sekolah dimana guru dan karyawan yang mendapatkan tanggungjawab dan tugas diberikan keleluasaan dan kewenangan oleh kepala sekolah dalam menjalankan apa yang menjadi tugas guru dan karyawan tersebut. Struktur orgnisasi disusun dan ditetapkan oleh kepala sekolah di awal tahun ajaran baru. Pemilihan guru dan karyawan yang menjabat dalam struktur organisasi menjadi kewenangan kepala sekolah untuk mempertimbangkannya dari segi kompetensi guru dan karyawan yang ditunjuk. Guru dan karyawan yang ditunjuk unutk menduduki jabatan struktural tertentu mendapatkan garis - garis kerja berupa tugas pokok dan fungsi jabatan.

Kepala sekolah mampu memberikan kewenangan dan keleluasaan kepada guru dan karyawan sekolah untuk merencanakan program disetiap awal tahun ajaran dan mengembangkan program - program yang ada menjadi lebih baik. Kepala sekolah sangat terbuka dengan ide dan gagasan yang lahir dari guru dan karyawan, terlebih ide dan gagasan tersebut adalah untuk percepatan terwujudnya tujuan sekolah.

Kepala sekolah senantiasa memantau berjalannya program yang ada di sekolah, khususnya program - program yang memberdayakan peserta didik untuk dapat tampil atau mengikuti ajang kompetisi berdasarkan minat, bakat dan kemampuan peserta didik. The school of champion adalah slogan yang dimasifkan oleh sekolah di masyarakat dengan maksud agar terbangun brand sekolah yang prestatif. Kepala sekolah memastikan pemetaan peserta didik yang memiliki minat dan bakat dilaksanakan dengan baik. Kepala sekolah mendorong kepada guru unutk tampil prestatif dengan memberikan pendampingan dan bimbingan yang maksimal kepada peserta didik yang diproyeksikan untuk mengikuti kompetisi.

Temuan - temuan di atas sesuai dengan yang disampaikan Sadler, 1997 (dalam Imam Machali, 2016: 101-102) terkait karakteristik pemimpin transformatif, yaitu: 1) Pemimpin menempatkan diri sebagai agen of change. 2) Mereka berani bertindak untuk melakukan perubahan, pemimpin tersebut berani menghadapi resistensi, menanggung resiko, dan berani menghadapi kenyataan. 3) Pemimpin percaya kepada pengikut, dengan cara mengembangkan kepercayaan melalui motivasi, kejujuran dan pemberdayaan, perduli terhadap aspek-aspek humanistik.

b. Mampu memberikan tindakan nyata yang memicu munculnya ide atau gagasan baru dalam menyelesaikan permasalahan melalui pemberdayaan bawahan.

Kepala sekolah dalam melaksanakan tugasnya sebagai pemimpin sekolah telah memperhatikan kebutuhan guru dan karyawan dalam hal peningkatan kompetensi mereka sebagai pendidik dan tenaga kependidikan. kepala sekolah sangat memperhatikan apa yang menjadi kebutuhan dari guru dan karyawan untuk dapat bekerja dengan rasa nyaman sehingga mampu memenuhi profesionalisme dalam bekerja di sekolah. Kepala sekolah telah mampu memberikan fasilitas 
kesejahteraan dan melengkapi sarana serta prasana penunjang guru dan karyawan dalam bekerja memberikan layanan pendidikan.

Kepala sekolah mampu menunjukkan diri sebagai pribadi yang ramah kepada siapa saja. Hal ini menghadirkan kesan bersahabat pada diri beliau sehingga orang yang bersinggungan dengan beliau akan mudah untuk merasa nyaman. Pola komunikasi yang diterapkan oleh kepala sekolah sama sekali tidak membedakan herarki struktur organisasi sekolah. Kepala sekolah merancang kegiatan - kegiatan penguatan untuk membangun hubungan kerja yang dinamis diantara guru dan karyawan. Kepala sekolah juga telah memberikan tugas - tugas menantang kepada guru dan karyawan untuk mampu menunjukkan prestasi diri.

Temuan di atas sesuai dengan hasil penelitian Ian A. Marshall (2014) Principal Leadership Style and Teacher Satisfaction Among A Sample of Secondary School Teachers in Barbados yang menyimpulkan adanya korelasi positif antara gaya kepemimpinan dengan kepuasan guru. Pertanyaan penelitian yang dijawab adalah apa yang bisa dilakukan untuk menimbulkan tingkat kepuasan yang lebih tinggi di antara para guru?. Titik awal yang baik adalah memfasilitasi guru di bidang pengembangan profesional, kepadatan kepemimpinan, dan keterlibatan dalam pengambilan keputusan pada saat yang sama. Hal tersebut menunjukkan adanya pemberdayaan guru dan karyawan yang dilakukan oleh kepala sekolah dalam usahanya mencapai tujuan dari setiap program sekolah..

\section{Penerapan dimensi individualized consideration oleh kepala sekolah dalam memimpin SDIT Muhammadiyah Al Kautsar}

a. Menunjukkan perilaku yang bersahabat, saling adanya kepercayaan, saling menghormati dan hubungan yang sangat hangat dalam kerja sama antara pemimpin dengan anggota kelompok.

Kepala sekolah dalam menjalankan kepemimpinannya telah menciptakan suasana iklim kerja yang nyaman melalui karakter keterbukaannya ketika berinteraksi dengan guru dan karyawan bai pada forum resmi maupun tidak resmi. Kepala sekolah sangat memperhatikan bawahan. Perhatian tersebut sering disampaikan dalam wujud apresiasi atau penghargaan. Salah satunya adalah adanya kebijakan penghargaan penambahan masa kerja bagi guru atau karyawan yang telah menyelesaikan studi lanjut. Selain itu beliau juga sangat menghargai kreatifitas bagi guru atau karyawan yang aktif dalam kepenulisan. Hal ini dapat dilihat dari kebijakan beliau yang memberikan insentif tambahan bagi guru karyawan yang kreatif dalam menulis.

Temuan di atas sesuai dengan apa yang disampaikan Sadler, 1997 (dalam Imam Machali, 2016: 101-102) terkait beberapa karakteristik pemimpin transformatif, yaitu: 1) Mereka berani bertindak untuk melakukan perubahan, pemimpin tersebut berani menghadapi resistensi, menanggung resiko, dan berani menghadapi kenyataan. 2) Pemimpin percaya kepada pengikut, dengan cara mengembangkan kepercayaan melalui motivasi, kejujuran dan pemberdayaan, 
perduli terhadap aspek-aspek humanistik. 3) Pemimpin transfomasional menjunjung tinggi nilai-nilai kemanusiaan seperti mengembangkan rasa empati dan simpati, saling menghargai, memperhatikan harkat dan martabat sesama, saling memedulikan, ramah, bertindak secara santun, perduli terhadap aspek-aspek pribadi, dan sosio-emosional.

b. Mampu memperhatikan kebutuhan bawahan/pengikut akan pengembangan karir.

Kepala sekolah sangat memperhatikan perkembangan kompetensi guru dan karyawan. Perhatian tersebut diwujudkan dalam bentuk kegiatan pelatihan. Kegiatan pelatihan guru dan karyawan diberikan sesuai dengan kebutuhan peningkatan kompetensi. Kegitan pelatihan guru dan karyawan diantaranya dalam bentuk seminar, in house training, workshop, dan lain - lain. Peningkatan kompetensi guru menjadi keharusan bagi sekolah swasta yang dituntut untuk selalu berbenah dan berupaya mengikuti perkembangan pendidikan di Indonesia. kepala sekolah memberikan kesempatan kepada guru dan karyawan untuk mengikuti pendidikan lanjut. Kepala sekolah memberi kelonggaran bagi guru dan karyawan yang sedang menempuh pendidikan lanjut, yakni dengan pengurangan beban tugas dan kelonggaran waktu. Kepala sekolah memiliki progam peningkatakan kompetensi guru karyawan melalui pemberian fasilitas pembiayaan pendidikan kepada guru dan karyawan yang melanjutkan pendidikan ke jenjang lebih tinggi.

Pertimbangan individual adalah memberikan perhatian pribadi, memperlakukan setiap karyawan secara individual, melatih dan menasehati (Danim, 2009: 57). Menurut Wahjosumidjo (1999: 24), bahwa pertimbangan individual (Individual consideration) menunjukkan perilaku yang bersahabat, saling adanya kepercayaan, saling menghormati dan hubungan yang sangat hangat dalam kerja sama antara pemimpin dengan anggota kelompok. Seorang pemimpin transformasional akan memperhatikan faktor-faktor individu sebagaimana mereka tidak boleh disamaratakan karena adanya perbedaan, kepentingan, latar belakang, sosial budaya, dan pengembangan pribadi yang berbeda satu dengan lain. Pemimpin transformasional akan memberikan perhatian untuk membina, membimbing dan melatih setiap anggota sesuai dengan karakteristik individu yang dipimpinnya.

\section{PENUTUP}

\section{Perenapan dimensi idealized influence oleh kepala sekolah dalam memimpin SDIT Muhammadiyah Al Kautsar}

Kepala sekolah menunjukkan integritas dalam memimpin sekolah dengan melibatkan guru karyawan dan stake holder dalam penyusunan visi, misi tujuan dan program sekolah kemudian berkomitmen menjalankan setiap program kerja sesuai dengan apa yang telah direncanakan. Kepala sekolah mampu menjadi teladan bagi guru karyawan dalam melaksanakan tugas di sekolah sesuai dengan perencaan yang dibuat dan regulasi yang ada. Kepala sekolah juga telah menunjukkan kemampuan dalam menyelesaikan permasalahan yang muncul di sekolah dengan melibatkan guru atau karyawan dalam setiap pengambilan keputusan. 
2. Penerapan dimensi inspirational motivation oleh kepala sekolah dalam memimpin SDIT Muhammadiyah Al Kautsar

Kepala sekolah telah menjadi inspirasi bagi guru dan karyawan dalam melaksanakan tugas dengan kemampuannya dalam mengkomunikasikan arah dan tujuan sekolah melalui kegiatan pembinaan atau rapat sekolah serta menunjukkan konsistensi dalam tindakan sehingga mendapatkan kepercayaan dari bawahannya. Kepala sekolah menunjukkan kemampuannya dalam memberikan motivasi kepada guru karyawan dengan memberikan penghargaan atau apresiasi terhadap hasil kerja dari guru dan karyawan serta memfasilitasi guru karyawan dengan baik secara perlakuan individu maupun kelompok, juga memfasilitasi dalam hal sarpras penunjang kenyamanan dalam pekerjaan.

3. Penerapan dimensi intelektual stimulation oleh kepala sekolah dalam memimpin SDIT Muhammadiyah Al Kautsar

Kepala sekolah mampu menerapkan kepemimpinan kolektif yakni dengan memdelegasikan tugas dan kewenangan kepada bawahan dalam menjalankan dan mengembangkan program - program sekolah yang berbasis prestasi. Pemberian tugas diwujudkan dengan penyusunan struktur organisasi sekolah berdasarkan kebutuhan program sekolah. Kepala sekolah menunjukkan tindakan nyata untuk memicu munculnya ide atau gagasan baru dalam menyelesaikan permasalahan melalui pemberdayaan bawahan dengan mengikutsertakan guru dan karyawan pada kegiatan diklat peningkatan kompetensi. Kepala sekolah membangun hubungan kerja yang dinamis dengan menghadirkan lingkungan kerja yang nyaman.

4. Penerapan dimensi individualized consideration oleh kepala sekolah dalam memimpin SDIT Muhammadiyah Al Kautsar

Kepala sekolah menunjukkan perilaku yang bersahabat, saling adanya kepercayaan, saling menghormati dan hubungan yang sangat hangat dalam kerja. Selain itu kepala sekolah juga telah memperlihatkan sikap toleransi, adil, demokratis dan menghargai perbedaan pendapat. Serta selalu memberikan apresiasi atas capaian positif bawahan. Kepala sekolah sangat memperhatikan kebutuhan bawahan akan pengembangan karir, yakni dengan memberikan kesempatan untuk mengikuti pelatihan dan memberikan kesempatan melakukan studi lanjut. 


\section{DAFTAR PUSTAKA}

Allen George P. 2016. The Role of Servant Leadership and Transformational Leadership in Academic Pharmacy, American Journal of Pharmaceutical Education, 80 (7) Article 113, Hal $1-7$.

Alwyn, Ian Marshall, 2015."Principal Leadership Style and Teacher Commitment among a Sample of Secondary School Teachers in Barbados". Journal of Arts \&Humanities Vol. 04, No. 05: 43-58

Antonakis, J., Avolio, B. J. \& Sivasubramanian, N. (2003) Context and leadership: An examination of the nine-factor full-range leadership theory using the multifactor leadershp questionnaire. The Leadership Quarterly, 14, pp. 261-295.

Avolio, B.J. \& Bass, B.M. (1994). Individual Consideration Viewed at Multiple Levels of Analysis : A Multilevel Framwork for Examining Te Diffusio of Transformational Leadership. Journal of Leadership Quarterly.6(2),199- 218.

Bass, B.M., Avolio, B.J., Jung, D.I. \& Berson, Y. (2003) Predicting unit performance by assessing transformational and transactional Leadership. Journal of Applied Psychology, 88 (2).

Burns, James MacGregor. 1978. Leadership. New York: Harper dan Row Publishers

Eliophotou Maria, Ioannou Androula. 2016. The Link Between Transformational Leadership and Teachers' Job Satisfaction, Commitment, Motivation to Learn, and Trust in The Leader, Academy of Educational Leadership Journal, 20 (3), Hal $12-22$.

Fatima Busra, Ahmad Usman, Asvir Naveed. 2011. Effect of Transformational Leadership on Employees' Job Satisfaction and Organizational Commitment in Banking Sector of Lahore (Pakistan). International Journal of Business and Social Science, Hal 261-267.

Hauserman Cal P., Stick Sheldon L. 2013. The Leadership Teachers Want from Principals: Transformational, Canadian Journal of Education, 36 (3), Hal 184 - 203.

Imam Machali, Ara Hidayat. 2016. The Handbook of Education Management. Jakarta: Prenadamedia Group.

Leithwood Kenneth dan Jantzi Doris. (1999). The Effects Of Transformational Leadership On Organizational Conditions And Student Engagement With School. Educational Resources Information Center (ERIC).

Mantja. 2007. Etnografi; Desain Penelitian Kualitatif Pendidikan dan Manajemen Pendidikan. Malang: Elang Mas

Maslow, Abraham H., (1954), Motivation And Personality, New York:Harper \& Row Publiser

Miles, Mathew B. dan Michael Huberman. 1996. Analisis Data Kualitatif. Jakarta: UI Press.

Moleong, Lexy J. 2007. Metodologi Penelitian Kualitatif. Bandung: PT. Remaja Rosdakarya.

Mulyana, Deddy. 2006. Metode Penelitian Kualitatif. Bandung : PT. Remaja Rosdakarya Nasution, S. 2004. Metode Penelitian Naturalistik-Kualitatif. Bandung: Tarsito Agung.

Onorato Michael. 2013. Transformational Leadership style In the Educational Sector: an Empirical Study of Corporate Managers and Educational Leaders, Academy of Educational Leadership Journal, 17 (1), Hal 33 - 47. 
Pierce, J.L., John W. Newstrom. (2006). Leader and The Leadership Process. New York : MicGraw Hill.

Rafiuddin. 2015. Konsep Dan Implementasi Gaya Kepemimpinan Transformasional Dalam Institusi Pendidikan Islam, Jurnal Ilmiah “Kreatif”, Vol. XII No. 1, Hal 1 -17 .

Robbins, Stephen. P. 2006. Perilaku Organisasi. Edisi Bahasa Indonesia. Indeks Kelompok Gramedia. Jakarta.

Roesminingsih Erny. (2014). Implementasi Kepemimpinan Transformasional di SD Muhammadiyah 4 Surabaya. Jurnal Inspirasi Manajemen Pendidikan, Vol.3 No.3, hlm. 56-65.

Sutopo HB. 2005. Metodologi Penelitian Kualitatif. Surakarta : Penerbit Sebelas Maret.

Satori, Djam'an dan Komariah, Aan. 2010. Metodologi Penelitian Kualitatif. Bandung: Alfabeta.

Singarimbun, Masri dan Sofian Effendi. 2004. Metode Penelitian Survei, Jakarta: LP3ES.

Sutama, 2019. Metode Penelitian Pendidikan, Kuantitatif, kualitatif, PTK, Mix Method, R\&D. Sukoharjo: CV. Jasmine

Sutopo. 2006. Metodologi Penelitian Kualitatif. Surakarta: UNS.

Tucker, L. R. \& Lewis, C., 2004. The influence of the Transformasional Leader.

Valentine Jerry W, Prater Mike. (2011). Instructional, Transformational, and Managerial Leadership and Student Achievement: High School Principals Make a Difference. NASSP Bulletin 95(1)

Wardhani Diah K., Anggan S I Gd., Yudana. Md. 2013. Implementasi Kepemimpinan Transformasional dalam Pengelolaan Sekolah, e-Journal Program Pascasarjana Universitas Pendidikan Ganesha, Volume 4.

Wutun, R.P. (2001). Pengembangan Kualitas SDM dari Perspektif PIO. Jakarta : Bagian Psikologi Industri dan Organisasi Fakultas Psikologi Universitas Indonesia.

Yammarino,F.Y dan Bass B.M. (1990). Long Term Forecasting or Transformational Leadership and Its Effect Among Naval officers. Group and Organizational Studies, 15:382-395. 